Міністерство освіти і науки України

Харківський національний педагогічний університет імені Г.С. Сковороди

B.В. Костіна

\title{
ПРОФЕСІЙНА ПІДГОТОВКА МАЙБУТНІХ ФАХІВЦІВ СОЦІАЛЬНОЇ ГАЛУЗІ ДО ПРОФІЛАКТИКИ ДЕЗАДАПТАЦІЇ УЧНІВ У РІЗНИХ СОЦІАЛЬНИХ ІНСТИТУЦІЯХ
}

Монографія

Харків 2018 


\section{DOI 10.26697/9786177089024.2018 \\ К 72}

Рекомендовано до друку Вченою радою

Харківського начіонального педагогічного університету імені Г.С. Сковороди (протокол № 3 від 24 квітня 2018 року)

\section{Рецензенти:}

I.М. Богданова - доктор педагогічних наук, професор, завідувач кафедри соціальної педагогіки, психології та педагогічних інновацій Державного закладу «Південноукраїнський національний педагогічний університет імені К.Д. Ушинського»;

O.I. Гуренко - доктор педагогічних наук, професор, професор кафедри соціальної роботи та інклюзивної освіти, перший проректор Бердянського державного педагогічного університету;

O.I. Рассказова - доктор педагогічних наук, професор, завідувач кафедри соціальної педагогіки та соціальної роботи КЗ «Харківська гуманітарно-педагогічна академія».

Костіна В. В.

К 72 Професійна підготовка майбутніх фахівців соціальної галузі до профілактики дезадаптації учнів у різних соціальних інституціях : монографія / В. В. Костіна. - Харків : ХОГОКЗ, 2018. - 364 с. doi:10.26697/9786177089024.2018

\section{ISBN 978-617-7089-02-4}

У монографії охарактеризовано значення різних соиіальних інституцій у профілактищі дезадаптащії учнів та визначено роль сочіальних педагогів та сочіальних працівників у ї̈ здійсненні, з'ясовано суть і особливості соціальної та соціально-педагогічної роботи з профілактики дезадаптації учнів у різних соціальних інституціях. Обтрунтовано концептуальні засади системи професійної підготовки майбутніх соиіальних педагогів $i$ сочіальних працівників до відповідного виду професійної діяльності та розроблено ї̈ модель $i$ науково-методичне забезпечення.

Для науковців, аспірантів і студентів педагогічних університетів, сочіальних педагогів, соціальних працівників, фахівцฺів, які праџюють у сфері соціальної роботи 3 учнівською молоддю.

За загальною редакцією доктора педагогічних наук, професора М.П. Васильєвої

УДК 378.147.013.42:364-78

ББК 74.580.22

ISBN 978-617-7089-02-4

(C) Харківський національний педагогічний університет імені Г.С. Сковороди, 2018

(C) В. В. Костіна, 2018

(C) ХОГОКЗ, оформлення, 2018 


\section{Зміст}

Вступ 5

Розділ 1 Профілактика дезадаптації учнів як

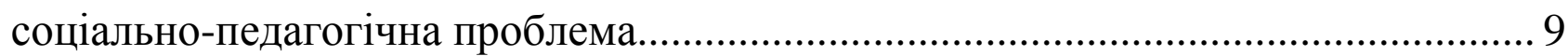

1.1 Дезадаптація у дітей та молоді: поняття, види, причини виникнення ........ 9

1.2 Профілактика дезадаптації учнів як проблема наукових досліджень ........ 28

1.3 Особливості діяльності різних соціальних інституцій у профілактиці дезадаптації учнів 39

1.4 Характеристика діяльності фахівців соціальної галузі

у профілактиці дезадаптації учнів у різних соціальних інституціях......... 45

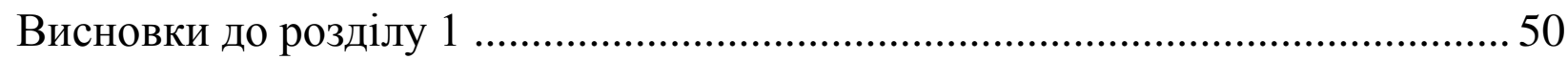

Розділ 2 Теоретичні засади профілактики дезадаптації учнів у різних

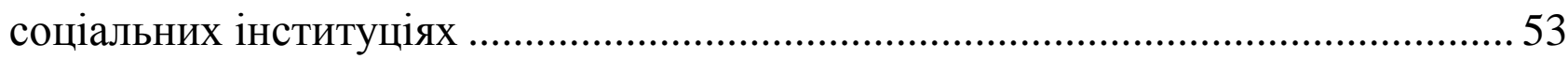

2.1 Профілактика дезадаптації учнів у закладах освіти та виховання............. 54

2.2 Профілактика дезадаптації учнів у закладах соціального

захисту дитинства 104

2.3 Профілактика дезадаптації учнів у закладах системи перевиховання та соціальної допомоги дітям-правопорушникам....................................... 130

2.4 Профілактика дезадаптації учнів з особливими потребами ...................... 140

2.5 Роль фахівців соціальної галузі у створенні партнерської мережі

соціальних інституцій, що здійснюють профілактику

дезадаптації учнів.

Висновки до розділу 2 148

Розділ 3 Теоретико-методологічні основи підготовки майбутніх фахівців соціальної сфери до профілактики дезадаптації учнів

3.1 Аналіз професійної підготовки майбутніх фахівців соціальної галузі до профілактики дезадаптації учнів (постановка проблеми)

3.2 Методологічне підгрунтя створення системи професійної підготовки майбутніх фахівців соціальної галузі до профілактики дезадаптації учнів.

3.3 Модель системи професійної підготовки майбутніх фахівців соціальної галузі до профілактики дезадаптації учнів.

3.4 Готовність майбутніх фахівців соціальної сфери до профілактики

дезадаптації учнів у різних соціальних інституціях

Висновки до розділу 3 
Розділ 4 Науково-методичне забезпечення підготовки майбутніх фахівців соціальної сфери до профілактики дезадаптації учнів

4.1 Технологічне забезпечення професійної підготовки майбутніх фахівців соціальної сфери до профілактики дезадаптації учнів.

4.2 Методичне забезпечення підготовки майбутніх фахівців соціальної сфери до профілактики дезадаптації учнів. 265

4.2.1 Методичні аспекти використання етнопедагогічних засобів у професійній підготовці майбутніх фахівців соціальної галузі до профілактики дезадаптації учнів. 268

4.2.2 Методичні аспекти професійної підготовки майбутніх фахівців соціальної сфери до формування здорового способу життя учнів як основи діяльності з профілактики їхньої дезадаптації. 275

Висновки до розділу 4 288

Загальні висновки 290

Література 295

Додатки. 332 


\section{ВСТУП}

Численні реформи суспільного розвитку призвели до поширення різноманітних кризових явищ, що зумовили появу великої кількості осіб, які виявилися дезадаптованими у сучасних реаліях життя. Особливої уваги потребує поширення цієї тенденції на дитячу та молодіжну аудиторію, що призвело до появи дітей, які за ознаками власної поведінки та особливостями соціалізації не можуть самостійно пристосуватися до нових умов життєдіяльності, відчувати себе повноправними суб'єктами суспільного життя, зокрема у закладах системи освіти та інших соціальних інституціях суспільства. Така категорія дітей потребує кваліфікованої допомоги 3 боку фахівців соціальної сфери, покликаних забезпечувати підтримку і супровід соціалізації дезадаптованих особистостей, проте важливою для суспільства є виконання фахівцями функції профілактики дезадаптації учнів, що дозволяє істотно зменшити їхню кількість.

Період навчання $є$ етапом соціалізації дитини, коли вона набуває важливих характеристик для успішного входження у суспільне життя за умови адаптації у соціальному середовищі навчального закладу чи певної соціальної інституції. Це зумовило необхідність підсилення соціальної функції закладів освіти та виховання, а також створення державою спеціальних соціальних інституцій (ЦССДМ, Центри соціально-психологічної реабілітації дітей, клініки дружні до молоді тощо), на які покладається профілактична функція, фахівці яких потребують професійної підготовки.

У зв'язку зі змінами, що відбулися у всіх сферах життя суспільства наприкінці XX - початку XXI ст., процес підготовки фахівців у сучасних умовах також потребує врахування новітніх тенденцій. Суспільне замовлення на активну, творчу висококваліфіковану особистість зумовлює необхідність у забезпеченні таких умов підготовки, які сприяють іiі самореалізації, більш повному розкриттю індивідуальних здібностей та можливостей, а також розвитку високого рівня професійної компетентності до певного виду діяльності, що можна досягти за допомогою здійснення підготовки майбутніх фахівців в умовах професійно-спрямованої освітньої системи. Одним із важливих напрямів професійної підготовки визнано підготовку майбутніх фахівців соціальної галузі (соціальних педагогів і соціальних працівників), які зможуть надавати кваліфіковану допомогу у профілактиці дезадаптації учнів, забезпечуючи запобігання появи різноманітних відхилень у їхній поведінці шляхом створення виховуючого середовища для їхньої успішної соціалізації. 
Аналіз наукової літератури 3 проблеми профілактичної роботи 3 дезадаптованими учнями показав, що в Україні та за кордоном накопичено чималий досвід у зазначеному напрямі. Дослідженими є такі аспекти проблеми: сутність та особливості профілактичної роботи з дезадаптованими учнями в Україні (О. Безпалько, І. Галатир, І. Звєрєва, В. Оржеховська, М. Малькова, С. Харченко та ін.); специфіка різних видів соціальної допомоги дезадаптованим учням за кордоном (Л. Бениш, І. Братусь, Р. Гілберт, У. Дейнет, Е. Мазліш, Е. Матцнер, Н. Щуркова та ін.); профілактика девіантної поведінки неповнолітніх (Ю. Василькова, Н. Максимова, Г. Федоришин та ін.); соціальнопедагогічні засади профілактики насильства в сім’ї (Л. Повалій, В. Постовий, В. Слот, Х Спаніярд, Т. Шульга та ін.).

Аналіз психолого-педагогічних досліджень з проблеми підготовки майбутніх фахівців до соціальної та соціально-педагогічної роботи 3 дезадаптованими учнями показав, що вивчено: теоретико-методологічні засади професійної підготовки майбутніх соціальних педагогів та соціальних працівників (О. Безпалько, І Богданова, О. Гуренко, І. Звєрєва, А. Капська, О. Карпенко, Г. Лактіонова, Л. Міщик, В. Поліщук, А. Рижанова, С. Харченко та ін.); теоретико-методичні основи загальної та спеціальної професійної підготовки майбутніх соціальних педагогів і соціальних працівників до зазначеного виду діяльності (С. Архипова, О. Білоліпцева, М. Васильєва, О. Лісовцець, М. Лукашевич, М. Малькова, І. Фірсова, 3. Фалинська, Р. Чубук та ін). Питання підготовки майбутніх соціальних педагогів та соціальних працівників до профілактичної роботи з учнями з девіантною поведінкою розглянуто у працях С. Архіпової, І. Козубовської, Г. Майбороди, Р. Новгородського, В. Поліщук, О. Тютюнник, О. Чусової та ін. Формування професійної готовності майбутніх педагогів i соціальних педагогів до роботи 3 профілактики жорстокого поводження 3 дітьми у сім’ї висвітлено у наукових працях І.Галатир, I. Манохіної, В. Приходько, Л. Шпальчак та ін. Підготовка майбутніх фахівців соціальної сфери до профілактики дезадаптації учнів з особливими потребами стала предметом наукових пошуків Т. Мальцевої, С. Нетьосова, О. Рассказової, П. Скляр, В. Тесленко та ін. Підготовка майбутніх соціальних педагогів до превентивної діяльності у закладах освіти та виховання досліджувалася О. Наконечною, Н. Синюк, М. Трухан, О. Чернишенко та ін. Однак, попри велику різноманітність дослідницьких робіт, проблема створення системи професійної підготовки майбутніх соціальних педагогів i соціальних працівників до профілактики дезадаптації учнів у різних соціальних інституціях $\epsilon$ недостатньо розробленою, відсутні теоретико-методологічні та технологічні 
основи підготовки майбутніх соціальних педагогів і соціальних працівників до відповідного виду професійної діяльності, які б повною мірою забезпечували професійне становлення, творчу самореалізацію та сомовдосконалення майбутніх фахівців у зазначеному напрямі.

Узагальнення та систематизація наукових джерел та практики професійної підготовки майбутніх фахівців соціальної сфери 3 проблеми дослідження дозволило нам обгрунтувати ідею необхідності створення цілісної системи професійної підготовки майбутніх соціальних педагогів і соціальних працівників до профілактики дезадаптації учнів у різних соціальних інституціях, що поєднує можливості закладів вищої освіти (ЗВО) (навчальна, виховна, науково-дослідна підсистеми) та інших соціальних інституцій партнерської мережі (підсистеми закладів освіти та виховання, соціальної допомоги та додаткової освіти, спеціалізованих інституцій) у підготовці фахівців до комплексного вирішення проблеми профілактики дезадаптації учнів.

Профілактика дезадаптації учнів у різних соціальних інституціях розглядається нами як складний багатоаспектний феномен, теоретичним підгрунтям якого є гуманістична парадигма, спрямована в широкому сенсі на підвищення якості життя учнів, як теорія i практика цілеспрямованої, комплексної, узгодженої діяльності різних соціальних інституцій, яку координують фахівці соціальної галузі (соціальні педагоги та соціальні працівники), що здійснюється на трьох рівнях (індивідуальному, мікро та макро) та має власну специфіку за різновидами (первинна, вторинна та третинна) й створює умови для забезпечення підвищення рівня адаптаційного потенціалу учнів, зниження дії чинників, які заважають їхньому успішному пристосуванню до умов мікро- та макросоціуму.

Профілактика дезадаптації учнів у різних соціальних інституціях передбачає здійснення комплексної професійної діяльності різних фахівців, спрямованої на запобігання появи можливих відхилень у поведінці учнів, що можуть зумовити їхню дезадаптацію: загальну, яку переважно здійснюють на рівні закладів, де навчаються учні, та спеціальну, що проводять працівники соціальних служб та спеціалізованих установ у разі появи специфічних проблем, які не може розв'язати соціально-психологічна служба закладу загальної середньої освіти (3ЗСО). Тому, з метою формування у майбутніх фахівців соціальної галузі готовності до здійснення комплексної діяльності 3 профілактики дезадаптації учнів, необхідною $\epsilon$ їхня професійна підготовка до виконання специфічної профілактичної діяльності з учнями у різних соціальних інституціях. 
У монографії наведено результати наукового пошуку та представлено теоретично обгрунтовану концепцію професійної підготовки, а також відповідну модель системи професійної підготовки майбутніх соціальних педагогів і соціальних працівників до профілактики дезадаптації учнів у різних соціальних інституціях та іï науково-методичне забезпечення. Загальна координація науково-теоретичних та емпіричних досліджень проводилася у Харківському національному педагогічному університеті імені Г.С. Сковороди.

Автор висловлює щиру вдячність вченим, рецензентам монографії: доктору педагогічних наук, професору Богдановій Інні Михайлівні, доктору педагогічних наук, професору Гуренко Ользі Іванівні та доктору педагогічних наук, професору Рассказовій Ользі Ігорівні за грунтовні наукові рекомендації щодо досліджуваної проблеми; а також науково-педагогічним колективам Криворізького державного педагогічного університету, Сумського державного педагогічного університету імені А.С. Макаренка, Харківського національного педагогічного університету імені Г.С Сковороди; колективам соціальних служб ЦСССДМ Київського та Холодногірського районів м. Харкова; фахівцям БФ «Благо» та БОБФ «Карітас-Харків»; колективам Харківського обласного центру соціально-психологічної реабілітації дітей та комунального закладу Харківський обласний центр соціально-психологічної реабілітації дітей «Гармонія», закладів загальної середньої освіти № 36, 43, 134, 169 м. Харкова за допомогу у проведенні експериментальної роботи та впровадження науковометодичного інструментарію підготовки майбутніх соціальних педагогів i соціальних працівників до профілактики дезадаптації учнів. 


\title{
ПРОФЕСІЙНА ПІДГОТОВКА МАЙБУТНІХ ФАХІВЦІВ СОЦІАЛЬНОЇ ГАЛУЗІ ДО ПРОФІЛАКТИКИ ДЕЗАДАПТАЦІЇ УЧНІВ У РІЗНИХ СОЦІАЛЬНИХ ІНСТИТУЦІЯХ
}

\author{
Монографія \\ ISBN 978-617-7089-02-4 \\ DOI 10.26697/9786177089024.2018 \\ Відповідальний випусковий: М.П. Васильєва \\ Комп'ютерна верстка: Л.Ю. Свстайло \\ Редактор: Б.П. Косіковська
}

Видано за рахунок автора

Підп. до друку 24.04.2018

Ум.-друк. арк. 21,2

Наклад 300 прим.
Формат 60х84 $1 / 16$

Гарнітура Times New Roman Обл.-вид. арк. 19,2 Друк - ризографія.

Зам № 1-20.

Харківський національний педагогічний університет імені Г.С. Сковороди Україна, 61002, Харків, вул. Алчевських, 29

Харківська обласна громадська організація «Культура Здоров'я»

Україна, 61105, м. Харків-105, пров. Забайкальський, 6, оф. 6 http://publisher.culturehealth.org/ тел./факс: +38 0577757523

E-mail: CultureHealth@ukr.net; KOSOCH@gmail.com

Свідоцтво про державну реєстрацію видавництва

ДК № 4387 від 10.08.2012 